DOI: $10.21802 / \operatorname{artm} .2020 .3 .15 .128$.

UDC 616.341-007.272-099-008-092. 9

\title{
SURGICAL PREVENTION AND TREATMENT OF POSTOPERATIVE HYPOPARATHYROIDISM IN PATIENTS OPERATED ON THYROID GLAND
}

\author{
A.Ya. Pasko \\ Ivano-Frankivsk National Medical University, Department of Surgery, Faculty of Dentistry, \\ Ivano-Frankivsk, Ukraine, \\ ORCID ID:0000-0002-6688-7666,e-mail:a.y.pasko@ukr.net
}

\begin{abstract}
Thyroid gland (TG) diseases are among the most common and occupy the second place in the structure of endocrine system diseases after diabetes mellitus. The main method of TG disease treatment remains the surgical one. With the increase in the incidence of various forms of TG pathology, the number of surgeries increases including the ones performed at non-specialized in-patient facilities leading to an increase in the frequency of postoperative complications.
\end{abstract}

One of the most common specific complications after surgeries on TG is postoperative hypoparathyroidism (PHPT). It occupies a special place considering the severity of manifestations and the difficulty in prevention. It is usually caused by trauma or parathyroid glands (PTG) removal, their blood supply disturbance, as well as the development of fibrosis at the surgery site in the long term.

Therefore, the improvement of existing technologies and the development of new approaches to surgeries in case of TG diseases are relevant today. The most common method of postoperative hypoparathyroidism (PHPT) surgical prevention is precision nature of surgical manipulations with careful adhering to tactical and technical requirements for the operator: identify parathyroid glands (PTG) timely, mobilize gently, and keep their blood supply. However, it is often impossible to keep PTG intact structurally and without ischemia due to the small sizes of PTG and their vessels, anatomical and embryological features of these organs localization, the consistency and color similarity with fatty tissue, lymph nodes.

The objective of the research was to develop and evaluate the algorithm of prevention and treatment of postoperative hypoparathyroidism (PHPT) based on determining parathyroid glands (PTG) viability and the use of antihypoxant-antioxidant therapy in the postoperative period. The research was based on the results of a comprehensive examination and treatment of 60 patients who were operated for thyroid gland diseases. The patients underwent inpatient treatment at the surgical department of Ivano-Frankivsk Central City Clinical Hospital and Ivano-Frankivsk Regional Oncology Center from 2017 to 2020.

We proposed an algorithm for surgical prevention and treatment of PHPT during thyroid gland surgeries which consisted in the following. We performed a visual assessment of PTG intraoperatively and evaluated each gland from 0 to 3 points according to the degree of its viability affection.

If the gland was evaluated at $0-2$ points, we left it, since there was a high probability of maintaining its function. If it was evaluated at 3 points, its autotransplantation was performed. Cytoflavin drug was applied in a dose of 10 $\mathrm{ml}$ per $2000.9 \% \mathrm{NaCl}$ intravenously once a day during 7 days in the postoperative period for the purpose of antihypoxant-antioxidant therapy.

2 groups of patients were formed in order to evaluate the effectiveness of the algorithm. Each group consisted of 30 people. Patients of Group I underwent surgery on thyroid gland according to generally accepted rules. Patients of Group II underwent interventions according to the above-mentioned algorithm.

The use of our proposed algorithm (intraoperative assessment of PTG viability and antihypoxant-antioxidant therapy in the postoperative period) significantly reduces the frequency of permanent PHP justifying indications to its application.

Keywords: postoperative hypoparathyroidism, assessment of parathyroid glands viability, treatment.

Introduction. Thyroid gland (TG) diseases are among the most common and occupy the second place in the structure of endocrine system diseases after diabetes mellitus. The main method of TG disease treatment remains the surgical one. With the increase in the incidence of various forms of TG pathology, the number of surgeries increases including the ones performed at nonspecialized in-patient facilities leading to an increase in the frequency of postoperative complications $[2,11]$.
One of the most common specific complications after surgeries on TG is postoperative hypoparathyroidism (PHPT). It occupies a special place considering the severity of manifestations and the difficulty in prevention. It is usually caused by trauma or parathyroid glands (PTG) removal, their blood supply disturbance, as well as the development of fibrosis at the surgery site in the long term [4].

Therefore, the improvement of existing technologies and the development of new approaches to surger- 
ies in case of TG diseases are relevant today. The most common method of postoperative hypoparathyroidism (PHPT) surgical prevention is precision nature of surgical manipulations with careful adhering to tactical and technical requirements for the operator: identify parathyroid glands (PTG) timely, mobilize gently, and keep their blood supply. However, it is often impossible to keep PTG intact structurally and without ischemia due to the small sizes of PTG and their vessels, anatomical and embryological features of these organs localization, the consistency and color similarity with fatty tissue, lymph nodes $[2,8]$.

Today, most researchers recommend the injured PTG to be left and autotransplantation to be conducted selectively in cases of their accidental removal. However, this approach is not without contradictions. Even if almost all PTG are left in situ, transient and even continuous PHPT still develops. Therefore, other researchers recommend autotransplantation of the PTGs that are considered nonviable. However, it is difficult to assess the extent of their damage in practice due to blood supply disturbance $[5,7]$. The commonly used method for PTGs viability assessment based on the study of changes in their external color cannot be considered reliable. Some researchers conducted a study aimed at assessing the influence of changes in PTG color after thyroidectomy on PHPT development. The authors concluded that functional impairment of PTGs that had changed the color occurred only temporarily and functional restoration was observed within a short period of time after the surgery. Autotransplantation of PTGs that have changed the color is not recommended in the absence of other criteria for autotransplantation. PTG physiological color in a typical anatomical site also does not always guarantee normocalcemia. Such PTG can be detected as a vascularized in the course of pathohistological study and cannot function after the surgery. Therefore, the color of the damaged PTG is not the final criterion for its viability. The integrity of its vascular pedicle should also be assessed $[6,9,10]$.

Up to the present moment, a non-alternative method of HPT treatment involves the use of exogenous administration of medication, namely calcium salt, vitamin D, its metabolites and/or analogues. This provides an opportunity to achieve satisfactory disease compensation in some patients [8]. However, methodological approaches and therapeutic agents not always maintain stable homeostasis in patients with HPT. A number of side effects and complications also occur (multi-systemic calcinosis, cataract, a pyretic tetanus, gastrointestinal diseases) [4].

The use of antihypoxic drugs is considered to be an effective way of prevention and intensive therapy of hypoxic (ischemic) damage due to surgery in clinics. Antihypoxic drugs weaken or completely eliminate hypoxic disorders (hypoergosis) by maintaining and increasing energy production in the system of mitochondrial oxidative phosphorylation. These drugs also inhibit (weaken)lipid peroxidation (LP) [1].

Considering the fact that Cytoflavin possesses the mechanism of biochemical correction of tissue oxygen transport and the consequences of hypoxic disorders, we made an assumption about the prospects of its use during TG surgeries in order to prevent and treat $\mathrm{TG}$ ischemic and reperfusion injury.

The objective of the research: to develop and evaluate the algorithm of prevention and treatment of PHPT based on determining PTG viability and the use of antihypoxant-antioxidant therapy in the postoperative period.

Materials and methods of the research. The research was based on the results of a comprehensive examination and treatment of 60 patients with various TG pathologies. They underwent inpatient treatment at the surgical department of Ivano-Frankivsk Central City Clinical Hospital and Ivano-Frankivsk Regional Oncology Center from 2017 to 2020. Their average age constituted 50.6 (46.6-60.2) years. The variety of surgeries on TG was the following: thyroidectomy was conducted in $53.3 \%$ of patients and thyroidectomy with central and peripheral lymph node dissection was performed in $46.7 \%$ of patients.

On admission to the hospital, all patients were performed standard laboratory and instrumental examinations. General and ionized calcium, phosphorus and parathormone $(\mathrm{PTH})$ were determined as well as ultrasound of the thyroid gland was performed to all patients. Testing with thiobarbituric acid according to E.I.Korobeynikova was conducted in order to evaluate the level of malondialdehyde (MDA). Diene conjugates (DC) in blood plasma were measured according to V.V.Havrylov method. Catalase was determined according to A. Bakh and S. Zubkova. The catalase blood count in healthy adults ranged from 9.52 to $12.92 \mathrm{mg}$ of hydrogen peroxide per $1 \mathrm{ml}$ of blood $\left(\mathrm{mgH}_{2} \mathrm{O}_{2} / \mathrm{ml}\right)[8,10]$. The principle of superoxide dismutase (SOD) determination was based on nitrotetrazolium restoration by superoxide radicals. One percent of nitroformazan formation blocking was considered as 1 relative unit(RU). SOD activity of a healthy person ranged from 60 to $80 \mathrm{RU}$ [3].

We proposed an algorithm for surgical prevention and treatment of PHPT during thyroid gland surgeries which consisted in the following. We performed a visual assessment of PTG intraoperatively and evaluated each gland from 0 to 3 points according to the degree of its viability affection. Thus, o points were given to PTG with unchanged color and normal blood supply. 1 point was given to the PTG which somewhat changed the color (it became brown) with partial blood supply disturbance but with moderate bleeding when incised. 2 points were given to the gland that changed its color to a dark brown with partial blood supply disturbance and with minimal bleeding observed during incision. The PTG which became dark brown or black, was completely devascularized and without bleeding at the site of the incision, was estimated at 3 points. Further approach to each PTG was determined according to the number of points. If the gland was evaluated at 0-2 points, we left it in situ, since there was a high probability of maintaining its function. If it was evaluated at 3 points, its autotransplantation was performed.

The total score of each patient was calculated in order to assess PHPT risk. The levels of PTH and $\mathrm{Ca}$ 
(general and ionized) were also determined immediately after the surgery.

The patient did not require correction and substitution therapy when a total score was $0-3$ and $\mathrm{Ca}$ and PTH levels were normal. $\mathrm{Ca}$ and vitamin $\mathrm{D}_{3}$ per os and antihypoxant therapy were prescribed in case of a total score amounting4-7 and lowered levels of $\mathrm{Ca}$ and PTH. $\mathrm{Ca}$ intravenously and vitamin $\mathrm{D}_{3}$ per os and antihypoxact therapy were prescribed when a total score amounted8-12 and $\mathrm{Ca}$ and PTH levels were lowered.

Cytoflavin drug was administered in a dose of $10 \mathrm{ml}$ per $2000.9 \% \mathrm{NaCl}$ intravenously once a day during 7 days in the postoperative period for the purpose of antihypoxant-antioxidant therapy. Cytoflavin is known to contain amber acid which increases tissues consumption of oxygen and improves tissue respiration by means of increase in electrons transport in mitochondria, the reproduction of the proton gradient on their membranes and shifting of oxyhemoglobin dissociation curve to the right, that is, it enhances the return of oxygen to the tissues. The drug activates intracellular synthesis of nucleic acids preserving ribosomes apparatus, enzymatic processes of Krebs cycle, promotes glucose disposal, synthesis and intracellular accumulation of ATP and other high-energy compounds. It also has antihypoxic properties, improves blood oxygenation, limits the area of ischemic injury and stimulates reparative processes [1].

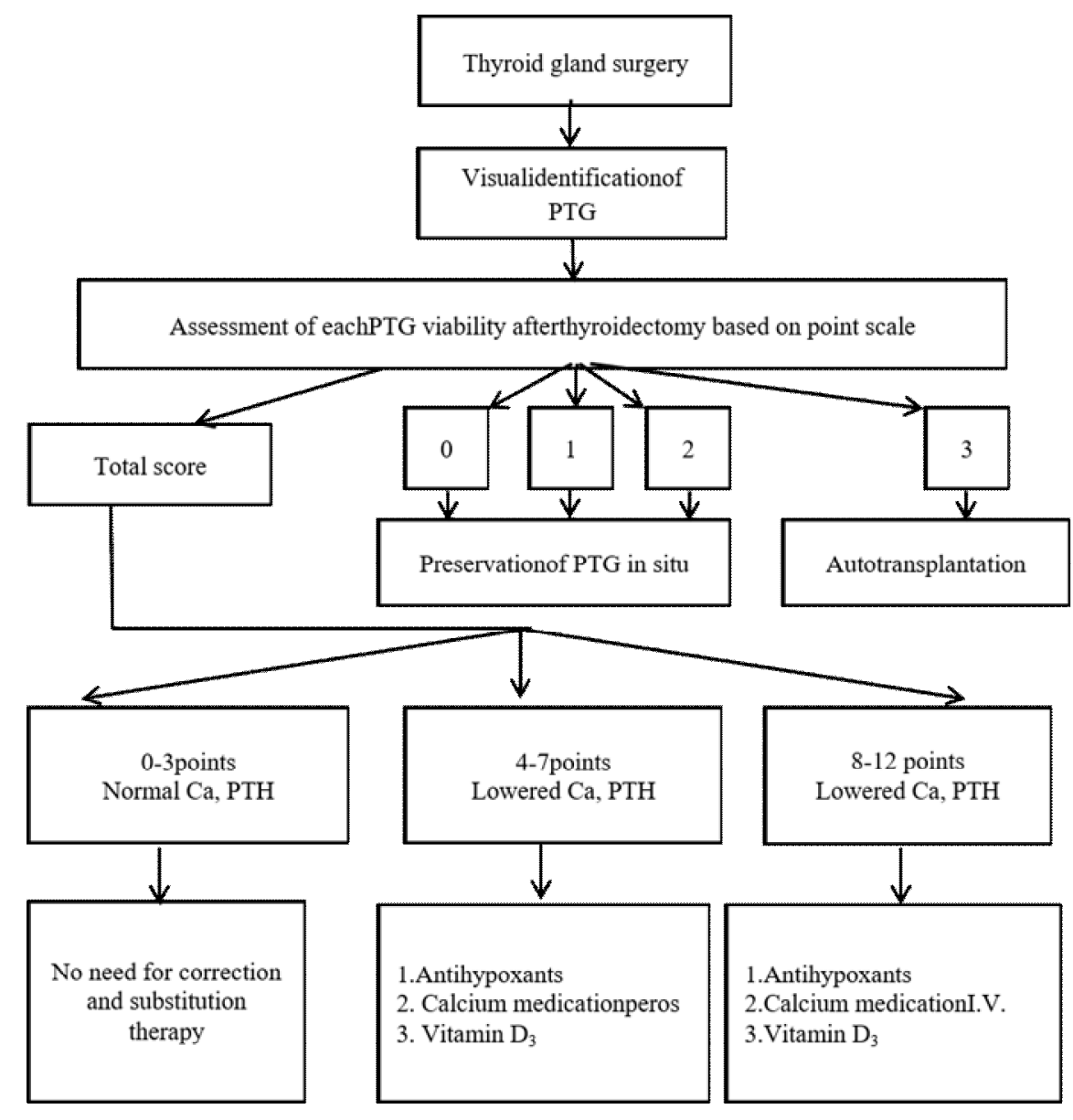

Fig.1. Algorithm of differentiated surgical prevention and treatment of PHPT

2 groups of patients were formed in order to evaluate the effectiveness of the algorithm. Each group consisted of 30 people. Patients of Group I (comparison group) underwent surgery on thyroid gland according to generally accepted rules, that is, all identified PTGs were left in situ as shown by existing standards. Patients of Group II (main group) underwent interventions according to the above-mentioned algorithm (Fig.1). $90.8 \%$ of possible PTGs were identified in Group II. $93.6 \%$ of them were left in situ, and $6.4 \%$ of them were autotransplanted into the sternocleidomastoid muscle. Autotransplantation was performed in 7 of 30 patients.

In order to obtain statistically significant data, the patients in both groups were carefully selected so that they did not differ statistically significantly in all the characteristics that could affect the results of the study.

Statistical processing of the results was conducted using the standard program package "Statistica 10.0 for Windows" (StatSoft, USA). The distribution of each of the studied variables was checked for "normality" with the use of Shapiro-Wilk test. Arithmetical mean (M) and mean-square deviation $(\sigma)$ were used to describe the variables with normal distribution. The description of variables with the distribution different from the normal one was performed using the median (Me) and lower and upper quartiles (q1 and q3). The assessment of significance of differences between the averages for the samples with normal distribution was performed with the use of 
Student's t-test. Mann-Whitney test was applied for the comparison of the indices, the distribution of which did not comply with the law of normality in two independent groups. Critical significance point (p) was considered to be 0.05 when checking the statistical hypotheses in the research.
Results of the research and their discussion. Analyzing the incidence of postoperative HPT symptoms (decrease in PTH and Ca) immediately after the surgery, significant differences in Group II in comparison with Group I were not noted. Thus, PHPT symptoms were detected in $53.3 \%$ of patients in Group I and in $50.0 \%$ of patients in Group II (Table 1).

Table 1

Postoperative dynamics of laboratory changes in the patients operated on TG depending on the treatment

\begin{tabular}{|c|c|c|c|c|c|c|c|c|}
\hline \multirow{3}{*}{ 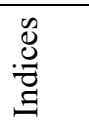 } & \multicolumn{8}{|c|}{ Patients operated on TG } \\
\hline & \multicolumn{4}{|c|}{ Group I $(n=16)$} & \multicolumn{4}{|c|}{ Group II $(n=15)$} \\
\hline & $1^{\text {st }}$ day & $7^{\text {th }}$ day & 1 month & 6 months & $1^{\text {st }}$ day & $7^{\text {th }}$ day & 1 month & 6 months \\
\hline 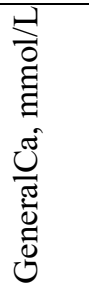 & $\begin{array}{c}2.21(2.11 ; \\
2.34)\end{array}$ & $\begin{array}{c}2.23 \\
(2.16 \\
2.38) \\
p>0.05\end{array}$ & $\begin{array}{c}2.25 \\
(2.17 \\
2.37) \\
\mathrm{p}>0.05 \\
\mathrm{p}_{1}>0.05 \\
\mathrm{p}_{3}>0.05\end{array}$ & $\begin{array}{c}2.24 \\
(2.18 \\
2.35) \\
\mathrm{p}>0.05 \\
\mathrm{p}_{1}>0.05 \\
\mathrm{p}_{3}>0.05\end{array}$ & $\begin{array}{c}2.23(2.14 \\
2.36)\end{array}$ & $\begin{array}{c}2.25(2.13 \\
2.29) \\
p>0.05\end{array}$ & $\begin{array}{c}2.24 \\
(2.12 ; \\
2.33) \\
\mathrm{p}>0.05 \\
\mathrm{p}_{1}>0.05 \\
\mathrm{p}_{2}>0.05 \\
\mathrm{p}_{3}>0.05\end{array}$ & $\begin{array}{c}2.22(2.14 ; \\
2.32) \\
\mathrm{p}>0.05 \\
\mathrm{p}_{1}>0.05 \\
\mathrm{p}_{2}>0.05 \\
\mathrm{p}_{3}>0.05\end{array}$ \\
\hline 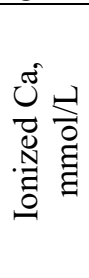 & $\begin{array}{c}0.72(0.62 ; \\
0.92)\end{array}$ & $\begin{array}{l}0.83 \\
(0.73 \\
0.98) \\
p>0.05\end{array}$ & $\begin{array}{c}0.87 \\
(0.76 ; \\
1.02) \\
\mathrm{p}>0.05 \\
\mathrm{p}_{1}>0.05 \\
\mathrm{p}_{3}<0.05\end{array}$ & $\begin{array}{c}0.93 \\
(0.87 \\
1.07) \\
\mathrm{p}<0.05 \\
\mathrm{p}_{1}>0.05 \\
\mathrm{p}_{3}<0.05\end{array}$ & $\begin{array}{c}0.71(0.63 \\
0.88)\end{array}$ & $\begin{array}{l}0.98(0.87 ; \\
1.12) \\
p<0.05\end{array}$ & $\begin{array}{c}1.08 \\
(0.97 \\
1.13) \\
\mathrm{p}<0.05 \\
\mathrm{p}_{1}<0.05 \\
\mathrm{p}_{2}>0.05 \\
\mathrm{p}_{3}>0.05\end{array}$ & $\begin{array}{c}1.12(1.05 \\
1.16) \\
\mathrm{p}<0.05 \\
\mathrm{p}_{1}<0.05 \\
\mathrm{p}_{2}<0.05 \\
\mathrm{p}_{3}>0.05\end{array}$ \\
\hline 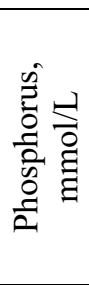 & $\begin{array}{c}1.83(1.47 \\
1.98)\end{array}$ & $\begin{array}{c}1.67 \\
(1.32 \\
1.83) \\
p>0.05\end{array}$ & $\begin{array}{c}1.45 \\
(1.23 ; \\
1.68) \\
\mathrm{p}<0.05 \\
\mathrm{p}_{1}>0.05 \\
\mathrm{p}_{3}<0.05\end{array}$ & $\begin{array}{c}1.23 \\
(1.12 \\
1.35) \\
\mathrm{p}<0.05 \\
\mathrm{p}_{1}<0.05 \\
\mathrm{p}_{3}>0.05\end{array}$ & $\begin{array}{c}1.82(1.54 \\
2.03)\end{array}$ & $\begin{array}{c}1.56(1.21 \\
1.75) \\
p<0.05\end{array}$ & $\begin{array}{c}1.18 \\
(1.11 ; \\
1.23) \\
\mathrm{p}<0.05 \\
\mathrm{p}_{1}<0.05 \\
\mathrm{p}_{2}<0.05 \\
\mathrm{p}_{3}>0.05\end{array}$ & $\begin{array}{c}1.12(1.06 ; \\
1.16) \\
\mathrm{p}<0.05 \\
\mathrm{p}_{1}<0.05 \\
\mathrm{p}_{2}<0.05 \\
\mathrm{p}_{3}>0.05\end{array}$ \\
\hline 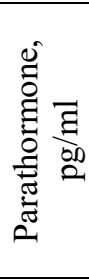 & $\begin{array}{c}6.7(5.8 ; \\
8.6)\end{array}$ & $\begin{array}{c}11.45 \\
(8.8 ; \\
13.4) \\
\mathrm{p}<0.05\end{array}$ & $\begin{array}{c}14.34 \\
(12.3 ; \\
16.56) \\
\mathrm{p}<0.05 \\
\mathrm{p}_{1}<0.05 \\
\mathrm{p}_{3}<0.05\end{array}$ & $\begin{array}{c}16.7 \\
(15.1 ; \\
18.6) \\
\mathrm{p}<0.05 \\
\mathrm{p}_{1}<0.05 \\
\mathrm{p}_{3}<0.05\end{array}$ & $\begin{array}{c}7.3(6.3 ; \\
8.2)\end{array}$ & $\begin{array}{c}18.4(15.4 \\
21.6) \\
p<0.05\end{array}$ & $\begin{array}{c}23.3 \\
(18.6 \\
27.6) \\
\mathrm{p}<0.05 \\
\mathrm{p}_{1}<0.05 \\
\mathrm{p}_{2}<0.05 \\
\mathrm{p}_{3}>0.05\end{array}$ & $\begin{array}{c}29.8(24.7 \\
35.6) \\
\mathrm{p}<0.05 \\
\mathrm{p}_{1}<0.05 \\
\mathrm{p}_{2}<0.05 \\
\mathrm{p}_{3}>0.05\end{array}$ \\
\hline
\end{tabular}

Note: $\mathrm{p}$ - the significance of difference in the indices on the $7^{\text {th }}$ day, in 1 month and in 6 months in comparison with the indices on the $1^{\text {st }}$ day;

$\mathrm{p}_{1}$-the significance of difference in the indices in 1 month and in 6 months in comparison with the indices on the $7^{\text {th }}$ day of the treatment; Group II;

$\mathrm{p}_{2}$ - the significance of difference in the indices in 1 month and in 6 months in Group I in comparison with

$\mathrm{p}_{3}$ - the significance of difference in the indices in 1 month and in 6 months in comparison with norm group.

Analyzing the dynamics of laboratory in dices depending on the treatment, we noted more rapid progress towards the normalization of ionized calcium, phosphorus and parathormone in Group II of patients in comparison with Group I. All the indices did not significantly differ in Group II of patients compared to the indices of the norm group, whereas significant abnormalities were observed in some patients of Group I even in 6 months. Thus, application of our algorithm contributed to faster restoration of PTG function and normalization of calcium-phosphorus metabolism (Table 2).

Analyzing the dynamics of lipid peroxidation indices depending on the treatment, significantly lower indices were noted in Group II of patients on the $7^{\text {th }}$ day in comparison with Group I. All the indices in Group II were not significantly different from those in the norm group in one month. Thus, the use of our algorithm, namely the medication with antioxidant antihypoxant action contributed to a faster reduction of peroxidation products.

The study of mechanisms of antioxidant system (AOS) functioning provides an opportunity to regulate the processes of lipid and protein peroxidation (Table 3). 
Table 2

Postoperative dynamics of lipid peroxidation indices in the patients operated on TG depending on the treatment

\begin{tabular}{|c|c|c|c|c|c|c|c|c|}
\hline & \multicolumn{4}{|c|}{ Group I $(n=16)$} & \multicolumn{4}{|c|}{ Group II $(n=15)$} \\
\hline & $1^{\text {st }}$ day & $7^{\text {th }}$ day & 1 month & 6 months & $1^{\text {st }}$ day & $7^{\text {th }}$ day & 1 month & $\begin{array}{c}6 \\
\text { months }\end{array}$ \\
\hline $\begin{array}{l}\mathrm{MDA}, \\
\mathrm{nM} / \mathrm{ml}\end{array}$ & $\begin{array}{l}8.62 \\
(6.17 ; \\
10.59)\end{array}$ & $\begin{array}{c}6.42 \\
(4.76 \\
8.69) \\
p>0.05\end{array}$ & $\begin{array}{c}4.78(3.58 \\
6.73) \mathrm{p}<0.05 \\
\mathrm{p}_{1}<0.05 \\
\mathrm{p}_{3}<0.05\end{array}$ & $\begin{array}{c}3.76(3.32 ; \\
4.65) \mathrm{p}<0.05 \\
\mathrm{p}_{1}<0.05 \\
\mathrm{p}_{3}>0.05\end{array}$ & $\begin{array}{l}8.58 \\
(6.12 ; \\
10.28)\end{array}$ & $\begin{array}{c}4.62(3.12 ; \\
5.98) \mathrm{p}<0.05\end{array}$ & $\begin{array}{c}3.77 \\
(3.43 ; \\
5.12) \mathrm{p}<0.05 \\
\mathrm{p}_{1}<0.05 \\
\mathrm{p}_{2}<0.05 \\
\mathrm{p}_{3}>0.05\end{array}$ & $\begin{array}{c}3.43 \\
(3.21 ; \\
3.68) \\
\mathrm{p}<0.05 \\
\mathrm{p}_{1}<0.05 \\
\mathrm{p}_{2}<0.05 \\
\mathrm{p}_{3}>0.05\end{array}$ \\
\hline $\mathrm{DC}, \mathrm{RU}$ & $\begin{array}{c}4.84 \\
(3.43 ; \\
5.69)\end{array}$ & $\begin{array}{c}3.46 \\
(3.12 \\
4.84) \\
\mathrm{p}>0.05\end{array}$ & $\begin{array}{c}2.12(1.57 \\
2.78) \mathrm{p}<0.05 \\
\mathrm{p}_{1}<0.05 \\
\mathrm{p}_{3}<0.05\end{array}$ & $\begin{array}{c}1.73(1.54 \\
2.12) \mathrm{p}<0.05 \\
\mathrm{p}_{1}<0.05 \\
\mathrm{p}_{3}>0.05\end{array}$ & $\begin{array}{c}4.95 \\
(3.58 ; \\
5.73)\end{array}$ & $\begin{array}{c}2.65 \\
(1.79 \\
2.98) \mathrm{p}<0.05\end{array}$ & $\begin{array}{c}1.52(1.24 \\
1.95) \mathrm{p}<0.05 \\
\mathrm{p}_{1}<0.05 \\
\mathrm{p}_{2}<0.05 \\
\mathrm{p}_{3}>0.05\end{array}$ & $\begin{array}{c}1.65 \\
(1.37 ; \\
2.09) \\
\mathrm{p}<0.05 \\
\mathrm{p}_{1}<0.05 \\
\mathrm{p}_{2}<0.05 \\
\mathrm{p}_{3}>0.05\end{array}$ \\
\hline
\end{tabular}

Note: $\mathrm{p}$ - the significance of difference in the indices on the $7^{\text {th }}$ day, in 1 month and in 6 months in comparison with the indices on the $1^{\text {st }}$ day;

$\mathrm{p}_{1}$-the significance of difference in the indices in 1 month and in 6 months in comparison with the indices on the $7^{\text {th }}$ day of the treatment; Group II;

$\mathrm{p}_{2}$ - the significance of difference in the indices in 1 month and in 6 months in Group I in comparison with

$\mathrm{p}_{3}$ - the significance of difference in the indices in 1 month and in 6 months in comparison with norm group.

Table 3

Postoperative dynamics of antioxidant system enzymes activity in patients operated on TG depending on the treatment

\begin{tabular}{|c|c|c|c|c|c|c|c|c|}
\hline \multirow{2}{*}{ Index } & \multicolumn{4}{|c|}{ Group I $(\mathrm{n}=16)$} & \multicolumn{4}{c|}{ Group II (n=15) } \\
\cline { 2 - 9 } & $1^{\text {st }}$ day & $7^{\text {th }}$ day & 1 month & 6 months & $1^{\text {st }}$ day & $7^{\text {th }}$ day & 1 month & 6 months \\
\hline & 5.45 & 6.65 & 8.54 & 9.78 & 5.38 & 9.76 & 10.12 & 10.56 \\
$\mathrm{CAT}, \mathrm{mg}$ & $(4.34 ;$ & $(5.12 ;$ & $(6.75 ;$ & $(8.69 ;$ & $(4.42 ;$ & $(6.87 ;$ & $(8.33 ;$ & $(9.24 ;$ \\
$\mathrm{H}_{2} \mathrm{O}_{2} / \mathrm{ml}$ & $5.99)$ & $7.09) \mathrm{p}<0$. & $9.83) \mathrm{p}<0$ & $10.12) \mathrm{p}<$ & $5.93)$ & $10.87) \mathrm{p}<$ & $11.2)$ & $12.35)$ \\
& & 05 & .05 & 0.05 & & 0.05 & $\mathrm{p}<0.05$ & $\mathrm{p}<0.05$ \\
& & & $\mathrm{p}_{1}<0.05$ & $\mathrm{p}_{1}<0.05$ & & & $\mathrm{p}_{1}<0.05$ & $\mathrm{p}_{1}<0.05$ \\
& & & $\mathrm{p}_{3}<0.05$ & $\mathrm{p}_{3}>0.05$ & & & $\mathrm{p}_{2}<0.05$ & $\mathrm{p}_{2}<0.05$ \\
& & & & & & & $\mathrm{p}_{3}>0.05$ & $\mathrm{p}_{3}>0.05$ \\
\hline & 29.15 & 41.15 & 49.15 & 53.98 & 26.18 & 49.87 & 61.98 & 65.13 \\
& $(19.72 ;$ & $(34.7 ;$ & $(38.7 ;$ & $(41.7 ;$ & $(17.6 ;$ & $(37.8 ;$ & $(56.5 ;$ & $(58.7 ;$ \\
& $39.14)$ & $48.76) \mathrm{p}<$ & $53.78) \mathrm{p}<$ & $58.92) \mathrm{p}<$ & $35.12)$ & $58.72) \mathrm{p}<$ & $65.72)$ & $69.87)$ \\
& & 0.05 & 0.05 & 0.05 & & 0.05 & $\mathrm{p}<0.05$ & $\mathrm{p}<0.05$ \\
& & & $\mathrm{p}_{1}<0.05$ & $\mathrm{p}_{1}<0.05$ & & & $\mathrm{p}_{1}<0.05$ & $\mathrm{p}_{1}<0.05$ \\
& & & $\mathrm{p}_{3}<0.05$ & $\mathrm{p}_{3}>0.05$ & & & $\mathrm{p}_{2}<0.05$ & $\mathrm{p}_{2}<0.05$ \\
& & & & & & & $\mathrm{p}_{3}>0.05$ & $\mathrm{p}_{3}>0.05$ \\
\hline
\end{tabular}

Note: $\mathrm{p}$ - the significance of difference in the indices on the $7^{\text {th }}$ day, in 1 month and in 6 months in comparison with the indices on the $1^{\text {st }}$ day;

$\mathrm{p}_{1}$-the significance of difference in the indices in 1 month and in 6 months in comparison with the indices on the $7^{\text {th }}$ day of the treatment; Group II;

$\mathrm{p}_{2}$ - the significance of difference in the indices in 1 month and in 6 months in Group I in comparison with

$\mathrm{p}_{3}$ - the significance of difference in the indices in 1 month and in 6 months in comparison with norm group.

In the course of the conducted research we noted significantly higher indices of catalase and SOD both on the $7^{\text {th }}$ day and in 1 month in the patients who took Cytoflavin in addition to the background therapy. Antioxidant effect of Cytoflavin is based on the ability to increase cellular anti-oxidants levels due to the active component, namely amber acid. Cytoflavin also indirectly stimulates the synthesis of low molecular weight antioxidants (ubiquinone, $\alpha$-tocopherol) [1].

Cytoflavin application in the comprehensive treatment of patients operated on TG provided a reduction of time of oxidative stress correction by preventing the growth of free radical oxidation activity and the for- 
mation of oxidative protein modification products with simultaneous stimulation of antioxidant defense system.

Analyzing the long-term effects of our algorithm application, we noted that HPT was transient in the patients of Group II and the level of PTH and ionized Ca normalized in a month, whereas decreased PTH and ionized $\mathrm{Ca}$ was found in $16.7 \%$ of patients in Group I even in 6 months, that is permanent HPT was observed in those patients.

Conclusions. The use of our proposed algorithm (intraoperative assessment of PTG viability and antihypoxant-antioxidant therapy in the postoperative period) significantly reduces the frequency of permanent PHPT justifying indications to its application.

\section{References:}

1. Danyliuk MB. Hypoparathyroidism as the main complication after thyroid surgery. Visnyk naukovykh doslidzen. 2016; 2:4-8.

2. Stack B, Bimstone D, Bodenner D, et al. American association of clinical endocrinologist and American college of endocrinology disease state clinical review: post operative hypoparathyroidism - definitions and management. EndocrPract. 2015; 21(6):675-684.

3. Anamaterou C, Lang $M$, Schimmackn S, et al. Autotransplantation of parathyroid grafts in muscle after parathyroidectomy: a novel autotransplantation site. BMC Surgery. 2015; 15:113.

4. Prazenica P, O'Keeffe L, Holy R, et al. Dissection and identification of parathyroidglands during thyroidectomy: association with hypocalcemia. Head Neck. 2015; 37:393-399.

5. Dzoric R, Santrac N. Insit up reservation of parathyroidglands: advanced surgical tips for prevention of permanent hypoparathyroidisminthyroid surgery. JBUON. 2017; 22(4):853-857.

6. Bollerslev J, Rejnmark L, Marcocci C, et al. European Society of Endocrinology clinical guide line: treatment of chronic hypoparathyroidismin adults. Eur J Endocrinol. 2015; 173(2):1-20.

7. Lang BH, Chan DT, Chow FC. Visualizing fewer parathyroid glands may be associated with lower hypoparathyroidism following total thyroidectomy. Langenbecks ArchSurg. 2016; 401:231-8.

8. Ji Y, Song Ch, Sung E, et al. Postoperative Hypoparathyroidism and the Viability of the Parathyroid Glands During Thyroidectomy. Clinical and Experimental Otorhinolaryngology. 2016; 13:1-7.

9. Kakava K, Tournis S, Papadakis G, etal. Postsurgical Hypoparathyroidism: A Systematic Review. Invivo. 2016; 30:171-180.
УДК 616.341-007.272-099-008-092. 9

ХИРУРГИЧЕСКАЯ ПРОФИЛАКТИКА И ЛЕЧЕНИЕ ПОСЛЕОПЕРАЦИОННОГО ГИПОПАРАТИРЕОЗА У БОЛЬНЫХ, ОПЕРИРОВАННЫХ НА ЩИТОВИДНОЙ ЖЕЛЕЗЕ

\section{А.Я. Пасько}

Ивано-Франковский национальный медицинский университет, кафедра хирургии стоматологического факультета, г. Ивано-Франковск, Украина, ORCID ID: 0000-0002-6688-7666,

e-mail:a.y.pasko@ukr.net

Резюме. Целью данного исследования было разработать и апробировать алгоритм профилактики и лечения послеоперационного гипопаратиреоза (ПГПТ) на основании определения жизнеспособности паращитовидных желез (ПЩЖ) и использовать антигипоксантно-антиоксидантную терапию в послеоперационном периоде. В основу исследования включены результаты комплексного обследования и лечения 60 больных, которые были прооперированы по поводу заболеваний щитовидной железы и находились на стационарном лечении в хирургическом отделении Ивано-Франковской центральной городской больницы и Прикарпатском клиническом онкологическом центре Украины с 2017 по 2020 годы.

Нами предложенный алгоритм хирургической профилактики и лечения ПГПТ при операциях на Щ3, который заключался в следующем: интраоперационно мы проводили визуальную оценку ПЩЖ и оценивали кардую железу от 0 до 3 баллов, соответственно до степени повреждения ее жизнеспособности.

Если железа была оценена от 0-2 баллов, мы оставляли ee insitu, так как существует высокая вероятность сохранения ее функции, при оценке железы в 3 балла мы проводили ее аутотрансплантацию. С целью антигипоксантно-антиоксидантной терапии мы применяли в послеоперационном периоде препарат Цитофлавин по 10 мл на $2000,9 \% \mathrm{NaCl}$ в/в 1 раз в сутки на протяжении 7 дней.

Для оценки эффективности алгоритма сформировано 2 группы пациентов по 30 человек. Больным I группы хирургические вмешательства на ЩЖ выполняли по общепринятым технологиям, а пациентам II группы - согласно вышеупомянутым алгоритмам.

Использование предложенного алгоритма (интраоперационная оценка жизнеспособности ПЩЖ и антигипоксантно-антиоксидантная терапия в послеоперационном периоде) достоверно снижает частоту постоянного ПГПТ, что обосновывает показания для его использования.

Ключевые слова: послеоперационный гипопаратиреоз, оценка жизнеспособности паращитовидных желез, лечение. 
УДК 616.341-007.272 - $099-008$ - 092.9

ХІРУРГІЧНА ПРОФІЛАКТИКА ТА ЛІКУВАННЯ ПІСЛЯОПЕРАЦИЙНОГО ГІПОПАРАТИРЕОЗУ В ХВОРИХ, ОПЕРОВАНИХ НА ЩИТОВИДНІЙ ЗАЛОЗІ

\section{А.Я. Пасько}

Івано-Франківський начіональний медичний університет, кафедра хірургіі стоматологічного факультету, м. Івано-Франківськ, Украӥна, ORCID ID: 0000-0002-6688-7666,

e-mail:a.y.pasko@ukr.net

Резюме. Метою цього дослідження було розробити і апробувати алгоритм профілактики та лікування післяопераційного гіпопаратиреозу (ПГПТ) на підставі визначення життєздатності паращитовидних залоз (ПЩЗ) і використовувати антигіпоксантноантиоксидантну терапію в післяопераційному періоді. В основу дослідження включені результати комплексного обстеження та лікування 60 хворих, які були прооперовані 3 приводу захворювань щитовидної залози і перебували на стаціонарному лікуванні в хірургічному відділенні Івано-Франківської центральної міської лікарні та Прикарпатському клінічному онкологічному центрі України з 2017 по 2020 роки.

Нами запропонований алгоритм хірургічної профілактики і лікування ПГПТ при операціях на
Щ3, який полягав в наступному: інтраопераційно ми проводили візуальну оцінку ПЩЗ і оцінювали кард залозу від 0 до 3 балів, відповідно до ступеня пошкодження іiі життєздатності.

Якщо залоза була оцінена від 0-2 балів, ми залишали iii insitu, так як існує висока ймовірність збереження іiі функції, при оцінці залози в 3 бали ми проводили іiї аутотрансплантацію. 3 метою антигіпоксантно-антиоксидантної терапії ми застосовували в післяопераційному періоді препарат Цитофлавін по 10 мл на 200 0,9\% $\mathrm{NaCl}$ в/в 1 раз на добу протягом 7 днів.

Для оцінки ефективності алгоритму сформовано 2 групи пацієнтів по 30 чоловік. Хворим I групи хірургічні втручання на ЩЗ виконували за загальноприйнятими технологіями, а пацієнтам II групи відповідно до вищезгаданого алгоритмом.

Використання запропонованого алгоритму (інтраопераційна оцінка життєздатності ПЩЗ і антигіпоксантно-антиоксидантна терапія в післяопераційному періоді) достовірно знижує частоту постійного ПГПТ, що обгрунтовує показання для його використання.

Ключові слова: післяопераційний гіпопаратиреоз, оцінка життєздатності прищитоподібних залоз, лікування.

Стаття надійшла в редакцію 29.06.2020 р. 